ROCZNIKI NAUK SPOŁECZNYCH

Tom 11(47), numer $4-2019$

DOI: http://dx.doi.org/10.18290/rns.2019.47.4-5

\title{
OD SEKULARYZACJI \\ DO POWROTU RELIGII NA SCENĘ PUBLICZNĄ: TRENDY ROZWOJOWE ŚWIATOWEJ SOCJOLOGII RELIGII Z UWZGLECDNIENIEM DOROBKU LUBELSKIEJ SZKOŁY SOCJOLOGII RELIGII W POLSCE**
}

\section{NARODZINY SOCJOLOGII RELIGII I JEJ PRZEDMIOT}

Początki socjologicznej refleksji nad religią zbiegają się z narodzinami socjologii jako nauki. Klasycy-fundatorzy dyscypliny, tacy jak August Comte, Herbert Spencer, Karol Marks, zajmowali się religią w taki sposób, że namysł nad jej obecnością był wmontowany w pewien sposób w ich wizje rozwoju społecznego, jego przebiegu a także ograniczeń. Nie miała ona jednak dla nich tak kluczowego charakteru jak w przypadku ich następców, Émila Durkheima i Maxa Webera, którzy z rozmachem tworzą rozległy teoretyczny gmach własnego, oryginalnego rozumienia społeczeństwa, kultury, odrębności socjologii jako nauki. I w obu przypadkach w tym gmachu refleksja nad religią ma fundamentalne znaczenie. $Z$ tego też względu Durkheima i Webera należy uznać za klasyków socjologii religii, podczas gdy ich poprzednicy zasługują na miano prekursorów.

Pierwszy okres rozwoju socjologii religii przypada umownie na przełom XIX i XX wieku. Klasycy definiują przedmiot nowej nauki szeroko, jako refleksję nad wzajemnym oddziaływaniem pomiędzy religią i społeczeństwem. Przy

Prof. dr hab. IRENA BoROwIK - Instytut Socjologii Uniwersytetu Jagiellońskiego; adres do korespondencji: ul. Grodzka 52, 31-044 Kraków; e-mail: uzborowi@cyf-kr.edu.pl, ORCID iD: https://orcid.org/0000-0003-3267-6913.

* Artykuł niniejszy został przygotowany w ramach realizacji grantu „Dyskurs publiczny w Polsce a religia. Modele legitymizacji w sporach wokół biopolityki w latach 2004-2014”. Projekt finansowany jest przez NCN w ramach konkursu OPUS7 (UMO-2014/13/B/HS6/03311). 
czym Durkheim kładzie nacisk na to, jak społeczeństwo kształtuje religię i jej formy, widząc jednostkę jako poddaną tym procesom i w zasadzie przez nie uprzedmiotowioną, podczas gdy Weber odwrotnie. Widzi on religię jako powstającą na swoiste zapotrzebowanie społeczne, na które jakaś wrażliwa jednostka wirtuoz religijny, charyzmatyczna osoba, lub określona warstwa społeczna, formułuje swoistą propozycję i potem ją podtrzymuje. Dla Webera powstanie religii, a potem jej upowszechnianie, jest napędzane ludzką potrzebą sensu, potrzebą nadania znaczenia podejmowanym działaniom, które religia legitymizuje ${ }^{1}$, i także owemu działającemu podmiotowi. Dla Durkheima zaś religia jest nieodzownym elementem tworzenia społeczeństwa, który to proces $w$ istocie jest religijny. Mówiąc inaczej i krótko, można powiedzieć tak: u Webera to jednostka jest religijna, w religii realizuje swoje idee przekształcając tym samym społeczeństwo, zaś u Durkheima to społeczeństwo jest ze swej istoty religijne i ogarnia swym wpływem jednostkę. Niezależnie od różnicy perspektywy, w przypadku obu klasyków religia i jej znaczenie jest swoistym kluczem dla zrozumienia społeczeństwa i miejsca, jakie w nim zajmuje człowiek.

Obaj klasycy, z punktu widzenia przewodu myślowego, który chcę tu rozwinąć, by pokazać pewien proces w sposobie konceptualizowania zmiany religijnej, położyli podwaliny pod rozumienie religii uformowane później, w latach 60 . i 70. XX wieku jako teorie sekularyzacji. Pomijając wiele innych istotnych wątków, a także drogi rozumowania, które Durkheima i Webera prowadziły do określonych wniosków, należy tu zwrócić uwagę na ich podstawowe konstatacje.

Społeczeństwo przełomu XIX i XX wieku, którego byli członkami, świadkami i interpretatorami, zmienia się dynamicznie i w określonym kierunku. Kierunek ten, ku nowoczesności, przynosi zdaniem Durkheima utratę przez religię funkcji integrującej społeczeństwo jako całość, uniezależnienie się od religii innych obszarów życia społecznego, takich jak nauka, obyczaje czy prawo ${ }^{2}$. W nowych okolicznościach jednostka wywyższa samą siebie i stawia, można powiedzieć, na miejscu, które niegdyś, w społeczeństwach prostszych, zajmowało sacrum. Zdaniem Webera zaś skutkiem rozwoju społeczeństw zachodnich jest ich racjonalizacja, ogarniająca świat kultury i samego człowieka, a to w efekcie

\footnotetext{
${ }^{1}$ Najważniejszym dziełem Webera jest Socjologia religii. Dzieła zebrane. Etyka gospodarcza religii światowych, tłum. D. Motak, G. Sowinski, T. Zatorski, Kraków: Zakład Wydawniczy Nomos 2006; por. także Szkice z socjologii religii, thum. J. Prokopiuk, H. Wandowski, Warszawa: KiW 1995. Również w jego dziele Gospodarka i społeczeństwo. Zarys socjologii rozumiejącej (tłum. D. Lachowska, Warszawa: PWN 2002) ponad 100 stron poświęconych jest religii.

${ }^{2}$ Najbardziej znanym dziełem Durkheima z zakresu socjologii religii jest książka wydana w języku polskim w 1990 r., tj. Elementarne formy życia religijnego, tłum. A. Zadrożyńska, Warszawa: PWN 1990. Jednak to $\mathrm{w}$ jego innych publikacjach rozsiane są uwagi na temat przemian religijnych w nowoczesności.
} 
przynosi odczarowanie świata, który staje się bardziej zmaterializowany, thumaczony w kategoriach przyczyny i skutku, z zawężającym się miejscem na cud i transcendencję tego, co powszednie.

Inną, bardzo ważną socjologiczną przesłankę tworzącą kontekst powstania teorii sekularyzacji, stanowiły badania empiryczne religijności społeczeństw chrześcijańskich, w tym w szczególności badania Gabriela Le Brasa dotyczące żywotności religijnej społeczeństwa francuskiego. Już w latach 40. i 50. XX wieku jego długofalowe badania pozwoliły na obserwację wybiórczości wierzeń i praktyk religijnych ${ }^{3}$, zwłaszcza w środowisku robotniczym i w wyniku migracji mieszkańców wsi do dużych miast. Również w innych społeczeństwach Europy Zachodniej obserwowano ten sam trend - zmniejszanie się częstotliwości praktyk religijnych. Inne elementy rzeczywistości podlegały w tym okresie dynamicznym zmianom, nie tylko indywidualne wierzenia i praktyki wskazywały na słabnięcie religii. Instytucje religijne, a szczególnie tzw. narodowe, dominujące Kościoły, stopniowo traciły monopol religijny i wpływ na pozareligijne sfery, w tym rozwój ekonomiczny odbywa się w całkowitym oderwaniu od religijnych norm. $\mathrm{Z}$ drugiej strony, postępuje indywidualizacja religijna, która oznacza, że nie tylko w szeroko rozumianym życiu społecznym, ale także w życiu jednostek, wpływ instytucji religijnych, religijny monopol w ofercie czy kontrola ,poprawności" - ulegają ograniczeniu i zawężeniu z racji przypisywania sobie przez jednostkę coraz większego zakresu decydowania o sobie, także w sferze religijnej.

Jednocześnie - w latach 60 , na tle rozwijającej się kontrkultury i ruchu hipisowskiego, niosącego hasła wolności i rewolucji seksualnej, powstał szereg nowych ruchów religijnych, które także stały się obiektem rozwijanych przez socjologów badań, a jednocześnie przyczyniły się do rosnącego pluralizmu sceny religijnej społeczeństw zachodnich i Stanów Zjednoczonych. A to właśnie w tych krajach dynamicznie rozwijała się socjologia religii.

Była jeszcze jedna, bardzo ważna przesłanka powstania teorii sekularyzacji, która wiązała się $\mathrm{z}$ dynamiką rozwoju socjologii religii jako nauki. W latach 60. i 70. XX wieku zaczął w środowisku socjologów religii narastać krytycyzm w stosunku do badań prowadzonych w środowiskach konfesyjnych, często motywowanych celami religijnymi, a słabo lub wcale niepowiązanymi z ogólniejszą refleksją teoretyczną, czy z próbą poszukiwania bardziej wyrafinowanych narzędzi badawczych.

${ }^{3}$ G. Le BRAs, Introduction à l'histoire de la pratique religieuse en France, 2 vol., Paris 19421945; Études de sociologie religieuse, 2 vol. (Bibliothèque de Sociologie contemporaine), Paris: Presses universitaires de France 1955-1956. 
Podniesione wyżej teoretyczne konstatacje Durkheima i Webera, empiryczne badania Le Brasa, obserwacje wspomnianych zmian społecznych i rozwój socjologii religii jako odrębnej subdyscypliny, stworzyły grunt sprzyjający dla powstania i rozwoju teorii sekularyzacji. Teorie sekularyzacji - chociaż używa się w stosunku do nich określenia ,paradygmat”, nigdy nie były niekwestionowaną interpretacją przemian religijnych $\mathrm{w}$ kręgu euro-amerykańskim. Od początku wyeksplikowania i podkreślenia wybranych tez klasyków ich interpretacja była wielokierunkowa, a teorie sekularyzacji nie stanowiły jakiegoś zwartego kompletu tez. I - co też ważne - formowały się w ogniu rozmaitych sporów i krytyk, które nie ucichły po dzień dzisiejszy, a także - prób dalszego rozwijania i modyfikacji teorii.

\section{KONCEPCJA SEKULARYZACJI: \\ NAJWAŻNIEJSZE TEZY}

Kanonicznym opracowaniem teoretycznym sekularyzacji stała się książka Petera Bergera Święty baldachim. Elementy socjologicznej teorii religii, wydana w języku angielskim w 1967 r. Berger sformułował kilka ważnych tez dotyczących miejsca religii w społeczeństwach podlegających modernizacji. Charakteryzując społeczeństwo, za najważniejsze jego cechy uznał pluralizm światopoglądowy, rozwój technologiczny, nieporównywalne w stosunku do przeszłości natężenie procesów komunikacyjnych, a każde z tych zjawisk posiada jego zdaniem dalekosiężny wpływ na zakres doświadczeń jednostki.

Sekularyzacja w rozumieniu Bergera, idącego tu tropami Webera, jest niejako wpisana $\mathrm{w}$ istotę judaizmu i chrześcijaństwa, poprzez koncepcję transcendentnego Boga, oderwanego od natury i niedoskonałego stworzenia, jakim jest człowiek, i oddalającego się coraz bardziej od ziemskiego świata w wyniku postępującej racjonalizacji. To racjonalizacja, w pierwszej kolejności manifestująca się w oderwaniu od religii życia gospodarczego i sekularyzacji procesu produkcji wszelkich dóbr, przenika następnie do innych sektorów życia społecznego, takich jak polityka (i państwo), sztuka, nauka czy nawet życie rodzinne. Religia i instytucje religijne stopniowo tracą wpływ na te segmenty życia społecznego i religia jako taka staje się sama w sobie obszarem ograniczonego znaczenia ograniczonego do własnej dziedziny. W wyniku sekularyzacji, jak pisze Berger: „Prawdopodobnie po raz pierwszy w historii religijne legitymizacje świata straciły swoją wiarygodność nie tylko dla kilku intelektualistów i innych nie liczą- 
cych się jednostek, lecz dla szerokich mas całych społeczeństw"4. W krótkim czasie wyjaśnianie przemian religijnych poprzez paradygmat sekularyzacji zyskało tyluż zwolenników, co i krytyków. Do tego grona należeli w owych początkach formowania się zrębów teorii tacy między innymi socjologowie, jak Talcott Parsons, Robert Bellah, Bryan Wilson - każdy z nich kładł nacisk na inne aspekty w swoim teoretyzowaniu.

Biorąc pod uwagę całą rozległą dyskusję, socjologowie identyfikują wiele różnorodnych obszarów sekularyzacji i można mieć wrażenie, iż właśnie w zależności od tego określają to, czym jest sekularyzacja jako taka. Mówią o:

- sekularyzacji w obrębie struktury i organizacji społecznej (oddzielenie państwa i Kościoła, uniezależnienie od religii instytucji życia społecznego, takich jak szkoła, rodzina, sądy, zakłady pracy, inaczej: uniezależnienie od religii innych niż religijny subsystemów społecznych: nauki, prawa, polityki, edukacji, kultury);

- sekularyzacji świadomości społecznej (tu takie zjawiska jak: ateizm, antyklerykalizm, obojętność religijna, selektywność akceptacji dogmatów wiary i zasad moralnych, upadek autorytetu funkcjonariuszy religijnych, krytycyzm i refleksyjność wobec świata przedstawień religijnych, spadek praktyk religijnych);

- zmianach w obrębie samej religii i instytucji religijnych (pluralizm i wzajemny szacunek dla pluralizmu ze strony wyznań; denominacjonalizm - zrównanie w szansach religii historycznych i młodszych wyznań, sekularyzacja instytucji religijnych: przyjmowanie świeckich wzorów i modeli działania w celu zwiększenia ich skuteczności);

- sekularyzacji jako słabnięciu instytucji religijnych (spadek powołań kapłańskich, występowanie z zakonów, starzenie się kadry kapłańskiej, pustoszenie kościołów i ich zamiana na centra kultury lub niszczenie).

Dyskusja tej teorii i krytyka także zależy od tego, który obszar czy aspekt jest brany pod uwagę.

\section{DYSKUSJA I KRYTYKA TEORII SEKULARYZACJI}

Stosunkowo wcześnie, bo już w latach 60. XX wieku główne słabości tego paradygmatu rozważał David Martin, ale dla dyskursu wokół tej teorii kluczowe znaczenie miały jego późniejsze książki. W pierwszej z nich, z 1978 r., zarzucał

${ }^{4}$ P. BERGER, Święty baldachim. Elementy socjologicznej teorii religii, tłum. W. Kurdziel, Kraków: Zakład Wydawniczy Nomos 1997, s. 171. 
teoriom sekularyzacji przede wszystkim ahistoryczność ${ }^{5}$. Co ciekawe jednak, po latach (i wielu innych doświadczeniach badawczych) Martin wrócił do refleksji nad teorią sekularyzacji i „nie wyrzuca jej do kosza”, ale próbuje rozwijać refleksję nad kwestiami, które podnosił wcześniej, i nowymi - w tym w szczególności rolą języka religijnego używanego w określonych kulturach ${ }^{6}$.

Teoria sekularyzacji była i dalej jest ${ }^{7}$ krytykowana $\mathrm{z}$ wielu punktów widzenia. Podkreśla się jej niespójność, to że nie wyjaśnia wszystkich religii i wszystkich krajów, a jest ograniczona do krótkiego okresu, i geograficznie - w największym stopniu do Europy. Mówi się o tym, że jest od samego początku nacechowana ideologicznie, czerpiąc korzenie z oświeceniowego przekonania o wyższości rozumu nad religią. Spór toczy się dalej i jako taki jest wielką wartością, prowadzi bowiem do rewizji teorii, która okazuje się nie tak „generalna” i uniwersalna jak pierwotnie się wydawało, ale też nie jest „windą, która jedzie tylko w dół" - jak ją kiedyś złośliwie określił Rodney Stark, który też nawoływał do jej pogrzebania. RIP - rest in peace, czyli ,spoczywaj w pokoju”, to fragment tytułu jednego $z$ jego artykułów na ten temat ${ }^{8}$.

Być może najłatwiej zgodzić się z ujęciem Danièle Hervieu-Léger, która twierdzi, iż sekularyzacji w ogóle nie należy rozumieć jako odchodzenia od religii, ale uznać ją trzeba za „dekompozycję” wiary. Owa dekompozycja zdaniem tej autorki jest procesem, w którym coraz większą rolę odgrywają indywidualne emocje i poszukiwania sacrum ${ }^{9}$. Grace Davie z kolei w swoich licznych publikacjach argumentowała, że niski poziom praktyk religijnych, jeden z elementów sekularyzacji świadomości, wcale nie musi być tak interpretowany, ponieważ

${ }^{5}$ D. MARTIN, A General Theory of Secularization, Hampshire: Gregg Revivals 1978.

${ }^{6}$ D. MARTIN, On Secularization: Towards a Revised General Theory, Aldershot: Ashgate 2005.

${ }^{7}$ Peter Berger po latach wrócił do tematu stwierdzając - mówiąc tu krótko - że się mylił, ale „w dobrym towarzystwie” popełniał błędy w interpretowaniu religijnej zmiany w kategoriach sekularyzacji. Co ciekawe jednak, kiedy czyta się jego ostatnie teksty i słucha wykładów (np. por. Peter Berger on the failure of the secularization hypothesis: https://www.youtube.com/watch?v=62zSUU9GGE, i: Dr. Peter Berger on Religion \& Modernity: https://www.youtube.com/watch?v=bv3a Lp27sO4, dostęp: 10.12.2018), to uderzają nie tylko te bon moty, które obiegły socjologiczny świat, jak ten, że świat dzisiaj jest „furiously religious”, ale też to, że „Europa jest zsekularyzowana”, i że różne elementy swoich koncepcji zmiany religijnej, które Berger w swoim czasie nazywał sekularyzacją, zostały podporządkowane innemu wiodącemu pojęciu - pluralizmowi (przemiany światopoglądowe jednostki, konfrontacja $\mathrm{z}$ innymi religiami, denominacjonalizm instytucji religijnych, konieczność dokonywania wyborów itp. itd. Nie ma tu miejsca na szczegółową analizę, chociaż kwestia podobieństwa ,składowych” jego koncepcji sekularyzacji i pluralizmu wydaje się fascynująca.

${ }^{8}$ R. STARK, Secularization, R.I.P, ,Sociology of Religion” 60(1999), No. 3, s. 249-273.

${ }^{9}$ D. Hervieu-Leger, Secularization. Tradition and new forms of religiosity: some theoretical proposals, w: New Religions and New Religiosity, red. E. Barker, M. Warburg, Aarhus: Aarhus University Press 1998, s. 28-44; por. TAŻ, Religia jako pamięć, tłum. M. Bielawska, Kraków: Zakład Wydawniczy Nomos 1999. 
brak praktyk nie oznacza koniecznej niewiary. Na dodatek, jak podkreśla, Europa na religijnej mapie świata jest wyjątkiem ${ }^{10}$. Z kolei zwolennik tej teorii, Steve Bruce powiada, że sekularyzacja jest faktem i „,istnienie nadnaturalnych istot, posiadających moc działania, lub bezosobowych mocy czy procesów posiadających moralne cele", w przeszłości było popularne, ale współcześnie nie jest ${ }^{11}$.

Problem oceny teorii sekularyzacji w dużym stopniu zależy od sposobu definiowania religii, jak to $\mathrm{w}$ swoich analizach tego paradygmatu ukazała Katarzyna Zielińska ${ }^{12}$. Substancjalne rozumienie religii generalnie preferuje perspektywę instytucjonalną, a zatem niższe praktyki religijne, albo nieortodoksyjne wierzenia mogą być interpretowane jako znak sekularyzacji. Funkcjonalne definicje religii, przeciwnie, sprzyjają takim ujęciom, które nie przywiązują wagi do ortodoksji religijnej, ale zwracają uwagę na to, że człowiek „tak w ogóle” w „coś” wierzy. To drugie ujęcie w wersji radykalnej zmierza w kierunku prywatyzacji religii, tak jak ją rozumiał Thomas Luckmann.

W dyskusji nad wartością teorii sekularyzacji z dzisiejszej perspektywy zgadzam się z tymi socjologami, którzy - jak cytowana już K. Zielińska ${ }^{13}$, albo Pippa Norris i Ronald Inglehart ${ }^{14}$ - sugerują, że warto myśleć kontekstowo, pod kątem badań, poszukiwania wskaźników, i właściwej operacjonalizacji przyjmowanych pojęć. Co innego jednak jest - jeśli tak można powiedzieć - jeszcze większą „zasługą" teorii sekularyzacji, mianowicie to, że z krytyki tej teorii wyrosło wiele nowych, socjologicznych koncepcji religii, w tym w szczególności dwie stoją w radykalnej do niej opozycji - ekonomiczna teoria religii Starka i jego współpracowników (Stark \& Bainbridge ${ }^{15}$, Stark \& Finke ${ }^{16}$ ) oraz José Casanovy powrotu religii na scenę publiczną. Na tej ostatniej chcę się tu skoncentrować, przede wszystkim dlatego, że wzbudziła najżywszy oddźwięk w środowisku socjologów.

${ }^{10}$ G. DAvIE, Europe: the Exceptional Case: Parameters of Faiths in the Modern World, London: Darton, Longman \&Todd 2002.

${ }^{11}$ S. BruCE, God is Dead: Secularization in the West, Oxford: Blackwell 2002, s. 58.

12 K. ZIELIŃSKA, Spory wokót teorii sekularyzacji, Kraków: Zakład Wydawniczy Nomos 2009, s.101-102.

${ }^{13}$ Tamże, s. 256-260.

${ }^{14}$ P. NoRris, R. Inglehart, Sacrum i profanum. Religia i polityka na świecie, tłum. R. Babińska, Kraków: Zakład Wydawniczy Nomos 2006.

15 R. StARK, W.S. BAinbridge, Teoria religii, tłum. T. Kunz, Kraków: Zakład Wydawniczy Nomos 2007.

${ }^{16}$ R. Stark, R. Finke, Acts of Faith. Explaining the Human Side of Religion, Berkeley-Los Angeles-London: University of California Press 2000. 


\section{CASANOVY KONCEPCJA RELIGII PUBLICZNEJ}

Głośna koncepcja Casanovy wyrasta z kilku przesłanek: dwie mają charakter teoretyczny, a dwie wywodzą się z obserwacji rzeczywistości społecznej - tego mianowicie, że Kościoły utrzymują znaczenie w przestrzeni publicznej, i że religia w wielu społeczeństwach jest ważnym obszarem doświadczeń, mobilizującym ludzi do działań w obronie określonych wartości.

Jeśli chodzi o przesłanki naukowe, to Casanova wyraża sprzeciw wobec kompleksu tez sekularyzacyjnych i odrzuca główną tezę Luckmanna o prywatyzacji religii. Sekularyzację jako teorię autor ten analizuje wyróżniając w niej trzy odrębne sfery czy też obszary jej funkcjonowania - jak sam to ujmuje - trzy nakładające się na siebie, a często niedające się oddzielić tezy. Próbuje je analitycznie wyodrębnić: pierwsza oznacza sekularyzację rozumianą głównie w kontekście dyferencjacji społecznej, druga to teza o „zmierzchu religii”, a trzecia - teza o prywatyzacji religii. Dwie ostatnie Casanova uznaje za mylnie wyprowadzane konsekwencje tezy pierwszej, takie, które nie są oparte na obserwacjach, ale na domniemanych konsekwencjach, jakie unowocześnianie społeczeństw, między innymi związane $\mathrm{z}$ dyferencjacją, ma mieć tak dla systemów społecznych, jak i dla jednostek.

Luckmann uważał (i tu szedł tropami Durkheima ${ }^{17}$ ), że religia w wyniku pluralizmu i indywidualizacji ulega prywatyzacji, czyli że staje się w coraz większym stopniu „własnością" jednostki, która, w sposób dostosowany do własnych potrzeb, poniekąd religię komponuje. Punktem wyjścia dla socjologów religii powinien jego zdaniem być pogląd na świat, albo inaczej - wizja świata. Każda jednostka „rodzi się” w określoną wizję świata, która jednocześnie jest wobec niej transcendentna (poprzez procesy obiektywizacji) i immanentna (poprzez internalizację). To właśnie wizja świata (światopogląd) jest zdaniem tego socjologa uniwersalną formą religii, a religia jest „transcendowaniem biologicznej i subiektywnej natury człowieka w obiektywne, pełne znaczeń uniwersum" ${ }^{18}$. Prywatyzacja w ujęciu Luckmanna nabiera wielorakich znaczeń: jest religią bez Kościoła, indywidualno-teologiczną odpowiedzialnością, religijnym subiektywizmem, rozdziałem kwestii religijnych i publicznych, oddzieleniem od religii moralności, wzrastającą selektywnością akceptacji prawd wiary, a także - pojawieniem się „nowych” tematów religijnych, takich jak seks, turystyka, psychoterapia.

17 Por. M.K. ZwIERŻDŻYŃSKI, Gdzie jest religia? Pięć dychotomii Thomasa Luckmanna, Kraków: Zakład Wydawniczy Nomos 2006.

18 Th. Luckmann, Niewidzialna religia. Problem religii $w$ nowoczesnym świecie, Kraków: Zakład Wydawniczy Nomos 1996, s. 84. 
Zdaniem Casanovy tylko ten pierwszy sposób rozumienia sekularyzacji, czyli sekularyzacja systemowa (w czym z dzisiejszej perspektywy nie jest on odosobniony) jest owocnym nurtem analizy religii we współczesności. Teorię prywatyzacji religii autor odrzuca jako swoistą nadinterpretację i formułuje tezę przeciwstawną - że współcześnie (angielskie wydanie Public Religions ma miejsce w 1994 r.) mamy do czynienia ze zjawiskiem deprywatyzacji religii.

Casanova znaczenie terminu ,sekularyzacja” (nie jako teorii, a jako pewnego rzeczywistego procesu historycznego) wyprowadza z - po pierwsze - średniowiecznego dualistycznego podziału rzeczywistości na świecką i sakralną, a następnie - z zaniku owego, charakterystycznego dla średniowiecza, dualizmu. Jak mówi, prowadzi to do upadku systemu pojęć opisujących ów świat, klasyfikacji, struktur, porządku, interpretacji rzeczywistości ${ }^{19}$. Ale jednocześnie teorię sekularyzacji uznaje za „oświeceniowy przesąd”, zakładający zmierzanie od epoki irracjonalizmu do epoki rozumu. W swoich ostatnich publikacjach z ironią i irytacją nawet pisze o tym, jak bardzo elity europejskie są przywiązane do zsekularyzowanego modelu Europy, w którym faktem jest spadek udziału Europejczyków w praktykach religijnych, ale jednocześnie, jeszcze istotniejsze jest jego zdaniem to, że ,ten spadek jest interpretowany przez «pryzmat paradygmatu sekularyzacyjnego», a co za tym idzie, towarzyszy mu «sekularystyczne samookreślenie», które uznaje ów spadek za «normalny» i «postępowy», co oznacza quasinormatywne konsekwencje bycia «nowoczesnym» «oświeconym» Europejczykiem"20.

Sekularyzacja jako teza zakorzeniona w historii daje się zdaniem Casanovy wywieść z reformacji protestanckiej, powstania nowoczesnego państwa, nowoczesnego kapitalizmu i nowoczesnej nauki. Przyjmując taką perspektywę stwierdza, że wobec odmiennego funkcjonowania tych elementów składowych w różnych państwach i różnych okresach należy przyjąc tezę, iż proces ten dokonuje się różnymi drogami, posiadać może odmienne dynamiki - i jako taki właśnie, a nie jako uniwersalny (fałszywy) model rozwoju (i upadania) religii zasługuje na zainteresowanie przedstawicieli nauk społecznych. Niezależnie od tych zastrzeżeń zdaje się, że Casanova bezsprzecznie w koncepcjach sekularyzacji widzi tę tezę jako owocną, zasługującą na dalszą penetrację, w kierunku odmiennym niż do tej pory.

19 J. CASANOva, Religie publiczne w nowoczesnym świecie, tłum. T. Kunz, Kraków: Zakład Wydawniczy Nomos 2005, s. 40.

20 Zob. J. CASAnova, Religion, European Secular Identities, and European Integration, https://www.eurozine.com/religion-european-secular-identities-and-european-integration/, 2004 [dostęp: 10.12.2018]. 
Kluczowa jest teza Casanovy o deprywatyzacji religii we współczesnym świecie. Przez deprywatyzację rozumie on proces polegający na powrocie religii na scenę publiczną społeczeństw, w których funkcjonuje. Powrót ów, czasem trwanie na tej scenie wynika $\mathrm{z}$ faktu, że jego zdaniem tradycje religijne na całym świecie odmawiają zaakceptowania zmarginalizowanej i sprywatyzowanej roli, zarezerwowanej dla nich przez teorie modernizmu oraz sekularyzacji. Efektem tej religijnej kontestacji są wzajemnie powiązane procesy: upolitycznienie prywatnej religii i moralności oraz przewartościowania w zakresie normatywizacji sfer publicznych, ekonomicznych i politycznych.

Religia, by właściwie w sferze publicznej funkcjonować, najczęściej występuje w dość określonej roli. Casanova mówi o trzech takich formach operowania na scenie publicznej. Pierwsza jest najbardziej klarowna, ma miejsce wówczas, gdy religia wchodzi „na scenę publiczną” występując w obronie gwałconych zasad wolności religijnej, jednocześnie występuje także w obronie wszystkich wolnościowych praw przypisanych ludziom. Druga ma miejsce wtedy, kiedy religia kontestuje dyferencjację funkcjonalną, pozwalającą na całkowitą niezależność etyczną i moralną sfer świeckich (kontestacja może dotyczyć niemoralności systemu ekonomicznego, niesprawiedliwości wolnego rynku, absolutyzmu prawa prywatnej własności itp.). Trzecia wynika z obrony tradycyjnych wartości moralnych.

Jeden z rozdziałów empirycznych książki Religie publiczne Casanova poświęcił analizie przypadku Polski i zaangażowania Kościoła rzymskokatolickiego w naszym kraju w obronę wolności i wspieranie ubezwłasnowolnionego społeczeństwa politycznego. W ogóle siła religijnych przekonań polskiego społeczeństwa, a także przeobrażeń roli Kościoła rzymskokatolickiego po upadku komunizmu i potencjalny przebieg tych procesów bardzo go interesowały. Zastanawiał się między innymi również nad tym, jakie skutki może mieć i dla Polski, i dla Europy wejście Polski do Unii Europejskiej.

Polski przypadek dla innych socjologów religii także jest $\mathrm{z}$ wielu względów interesujący. Po pierwsze - w naszym kraju utrzymuje się wysoki poziom religijności. Po drugie - polskie społeczeństwo zostało doświadczone przez konfrontację z ideologią zwalczającą religię. Po trzecie - Polska jest krajem, w którym, pomimo albo wbrew komunizmowi, socjologia, w tym także socjologia religii, należała do jednej z najbardziej rozwiniętych w tej części Europy. A duże zasługi w tej materii leżą po stronie środowiska Katolickiego Uniwersytetu Lubelskiego. 


\section{SOCJOLOGIA RELIGII W POLSCE - ZARYS ZNACZENIA LUBELSKIEJ SZKOŁY}

Socjologia religii rozwijana na Katolickim Uniwersytecie Lubelskim miała kluczowe znaczenie dla rozwoju tej subdyscypliny w Polsce, zarówno w sensie organizacyjnym, związanym z instytucjonalizacją nauczania, jak i w sensie dorobku merytorycznego - publikacji i prowadzonych badań

Instytucjonalizacja socjologii religii jako nauki w Polsce w postaci katedr i zakładów to proces zapoczątkowany przez jej przedstawicieli związanych instytucjonalnie $\mathrm{z}$ Kościołem rzymskokatolickim, i właśnie Katolickiemu Uniwersytetowi Lubelskiemu przypada w tej materii palma pierwszeństwa. Już w 1927 r. ks. Franciszek Mirek, uczeń Floriana Znanieckiego, publikuje pionierską książkę Elementy spoteczne parafii rzymsko-katolickiej. Wstęp do socjologii parafii, która ma niewątpliwe walory naukowe i zostaje uznana przez środowisko socjologiczne za znaczące dokonanie ${ }^{21}$. Bardzo ważne były zasługi tego uczonego dla emancypacji młodej nauki, jaką była wówczas socjologia. Stał on bowiem jednoznacznie na stanowisku neutralności światopoglądowej badań socjologicznych, co w tamtych czasach, kiedy równolegle była rozwijana tzw. socjologia chrześcijańska, nastawiona na praktyczne zastosowanie tej nauki do celów religijnych, wcale nie było oczywiste.

W 1958 r. powstała tu pierwsza Katedra Socjologii Religii, w Instytucie Teologii Pastoralnej na Wydziale Teologicznym, w 1992 r. decyzją Senatu Akademickiego KUL przeniesiona na Wydział Nauk Społecznych. Kierowana była właśnie przez ks. Józefa Majkę, następnie, od 1970 r. przez ks. Władysława Piwowarskiego. Inny zasłużony socjolog religii, ks. Janusz Mariański, w 1984 r. na tejże uczelni założył i przez wiele lat kierował Katedrą Socjologii Moralności, jednocześnie, od 2001 r. pełniąc funkcję opiekuna Katedry Socjologii Religii. Obecnie obie katedry zostały połączone z innymi, i tak Katedra Socjologii Prawa i Moralności została utworzona z początkiem 2015 r. poprzez połączenie dwóch katedr - Socjologii Prawa i Socjologii Moralności (http://www.kul.pl/informa cje-o-katedrze,art_4753.html, dostęp: 15.12.2018). Z kolei Katedra Socjologii

${ }^{21} \mathrm{Na}$ Uniwersytecie Warszawskim socjologia religii pojawiła się w programie studiów w roku 1934, nauczana przez prof. Stefana Czarnowskiego do jego śmierci w 1937 r., a następnie w roku akademickim 1947/1948, jako wykład kursowy w Katedrze Socjologii, prowadzony przez prof. Jana Stanisława Bystronia. W całym tym okresie socjologia religii instytucjonalnie nie jest wyodrębniona, a jej nauczanie zależy od pasji naukowych wykładających profesorów, czyli od tego, czy akurat interesują się socjologią religii. 
Religii weszła w skład utworzonej w 2014 r. Katedry Socjologii Kultury i Religii (http://www.kul.pl/informacje-o-katedrze,art_51562.html, dostęp: 15.12.2018) ${ }^{22}$.

Recepcja nurtów teoretycznych rozwijającej się światowej socjologii religii w Polsce $z$ wielu powodów następowała powoli. Po pierwsze - socjologia jako taka przed II wojną światową była w pierwszej fazie rozwoju, a jej pozycja jako nauki dopiero stopniowo się krystalizowała. Po drugie - po II wojnie światowej zarówno socjologia, jak i religia jako przedmiot zainteresowań socjologów znalazły się pod ostrzałem prześladowań komunistycznych władz. Co prawda, nie miały one tak rozległego charakteru jak w innych krajach Europy ŚrodkowoWschodniej $^{23}$, tym niemniej także w Polsce toczyła się (ostatecznie z niewielkim powodzeniem) ateizacja, do której próbowano zaprzęgać ośrodki naukowe. Ograniczony był dostęp do literatury obcojęzycznej, niewiele wydawano tłumaczeń, uprzystępniających światowe dzieła. Zmieniło się to gwałtownie dopiero po $1989 \mathrm{r}$.

Jednak, z drugiej strony, w Polsce była o wiele większa swoboda rozwoju niezależnej myśli naukowej niż w innych krajach bloku wschodniego, i dotyczyło to w dużym stopniu właśnie socjologii religii. W znacznym stopniu było to zasługą środowisk katolickich i - generalnie - silnej pozycji katolicyzmu i Kościoła rzymskokatolickiego. W tym zakresie znaczenie środowiska KUL-u, które z czasem zyskało nazwę lubelskiej szkoły socjologii religii, było nie do przecenienia. Badania prowadzone przez jego przedstawicieli, neutralna orientacja metodologiczna, związek ze światową socjologią religii stanowiły skuteczną przeciwwagę i konkurencję wobec badań ośrodków popieranych przez PZPR. Dzięki temu zresztą te ostatnie także musiały stosować standardy właściwe naukom empirycznym. W największym stopniu są to zasługi, które w okresie powojennym można przypisać dwóm uczonym tego środowiska - Władysławowi Piwowarskiemu i Januszowi Mariańskiemu, oraz szeregowi uformowanych przez

22 Obecnie w Polsce, poza dwoma wyżej wspomnianymi katedrami, istnieje kilka ośrodków naukowych, prowadzących działalność dydaktyczną i badawczą w zakresie socjologii religii: w Instytucie Socjologii na UKSW i na UJ, w Instytucie Religioznawstwa UJ, na Uniwersytecie Pedagogicznym w Krakowie. Ponadto socjologowie religii pracują na wielu innych uniwersytetach, gdzie nie ma jednostek wyodrębnionych, zajmujących się socjologią religii. Wielu z nich jest członkami sekcji socjologii religii Polskiego Towarzystwa Socjologicznego, powołanej w 1987 r. z inicjatywy zasłużonych socjologów religii: ks. prof. Władysława Piwowarskiego i prof. Edwarda Ciupaka, przy współpracy ks. prof. Witolda Zdaniewicza (por. http://pts.org.pl/sekcje/sekcja-socjologiireligii/, dostęp: 15.12.2018). Do rozwoju prac tej sekcji w dużym stopniu przyczynił się Janusz Mariański, a także Maria Libiszowska-Żółtkowska.

${ }^{23}$ Por. I. BorowiK, Sociology of Religion in Central and Eastern Europe after 1989, w: Eastern European Religion, red. E. Revay, M. Tomka, Budapest-Piliscaba: Pazmany Tarsadalomtudomany 2006, s. 33-48. 
nich uczniów (w obu przypadkach ponad pięćdziesięciu wypromowanych doktorów, w tym w przewadze z zakresu socjologii religii i socjologii moralności).

Uczeni ci antycypowali dyskusje toczące się w nauce i aplikowali ustalenia teoretyczne do własnych badań. Charakteryzowane tu koncepcje sekularyzacji wcześnie, bo już w latach 70. XX wieku, były przedmiotem refleksji Piwowarskiego, a później, kiedy prowadził rozległe badania empiryczne nad religijnością wiejską i miejską ${ }^{24}$, rozważając typowe elementy tych teorii, czyli powiązanie sekularyzacji z industrializacją, modernizmem i pluralizmem, stwierdzał, że przemian religijnych występujących w Polsce nie można interpretować na podstawie schematów wypracowanych na Zachodzie ${ }^{25}$.

Nieprzypadkowo najbardziej rozwinięty nurt empirycznych zainteresowań polskiej socjologii religii stanowią badania dotyczące religijności i parafii - wpisują się one bowiem w istniejącą w Polsce najdłużej tradycję, zapoczątkowaną przez ks. Mirka i znajdującą później licznych kontynuatorów. Ks. J. Majka rozwijał badania żywotności religijnej, wzorujące się na prowadzonych we Francji badaniach Le Brasa $^{26}$. Kluczowe $\mathrm{w}$ tej materii były niewątpliwe dokonania ks. W. Piwowarskiego, który uprzystępnił w Polsce dorobek amerykańskich, niemieckich i francuskich socjologów religii i stworzył kompleksową koncepcję religijności, którą zastosował w badaniach będących wzorem dla wielu socjologów po dzień dzisiejszy.

Ks. Piwowarski był socjologiem, którego obcojęzyczne publikacje na temat religii w Polsce stały się znane już w latach 60 . XX wieku, a w następnych dekadach także publikował w języku angielskim, niemieckim i francuskim, uczestnicząc w międzynarodowym życiu naukowym i referując wyniki własnych badań. Właśnie on, a później ks. J. Mariański w sposób zdecydowany przyczynili się do trwałego wzbogacenia dorobku socjologii religii, prowadząc rozległe własne badania, promując wielu doktorów, dyskutując światowy dorobek socjologii.

Jedną z szerzej i krytycznie omawianych w Polsce była właśnie teoria sekularyzacji, której założenia, szczególnie te dotyczące spadku religijności, nie były przydatne do thumaczenia dynamiki przemian religijnych w Polsce i prowokowały jej krytykę. Założenie o sekularyzacji świadomości religijnej nie były przydatne, ponieważ w Polsce po II wojnie religijność społeczeństwa polskiego po-

\footnotetext{
${ }^{24}$ Ważne są tu przede wszystkim dwie książki, stanowiące rozległe i rzetelne studia religijności: Religijność wiejska $w$ warunkach urbanizacji: studium socjologiczne, Warszawa: Biblioteka „Więzi” 1971 i Religijność miejska w rejonie uprzemysłowionym: studium socjologiczne, Warszawa: Biblioteka „Więzi” 1977.

${ }^{25}$ W. PIWOWARSKI, Socjologia religii, Lublin: Redakcja Wydawnictw KUL 1996, s. 315.

${ }^{26}$ J. MAJKA, Jaki jest katolicyzm polski?, w: Socjologia religii. Wybór tekstów, red. F. Adamski, Kraków: WAM 1983, s. 258-274.
} 
zostawała cały czas na bardzo wysokim poziomie, a w latach $80 . \mathrm{XX}$ wieku nawet wzrosła, czyli podlegała tendencjom zupełnie odwrotnym niż w Europie Zachodniej. W tym okresie Piwowarski wolał mówić o selektywnej religijności, mając na myśli to, że nie wszystkie wierzenia i normy moralne są akceptowane w równym stopniu, a nieco później Mariański wolał mówić o indywidualizacji, mając na myśli to, że coraz większą rolę w akceptowaniu prawd wiary i norm moralnych jednostka przyznaje samej sobie.

Ujęcie religijności popularyzowane w ramach lubelskiej szkoły socjologii religii reprezentowanej przez Piwowarskiego, było zdominowane przez perspektywę instytucjonalną i kościelną ${ }^{27}$. Typowe dla tego ujęcia było traktowanie jako normy tych postaw wobec religii, które są określane przez Kościół rzymskokatolicki, a jednoczesne uznawanie indywidualizacji w zakresie wiary i moralności za odstępstwo od niej. Należy przy tym jednak zaznaczyć, że w latach 70. i 80. XX wieku przyjęcie w Polsce innej perspektywy było bardzo utrudnione. Społeczeństwo polskie pod względem religijnym było bardzo jednorodne, a religijność mocno powiązana z Kościołem rzymskokatolickim. Dopiero po 1989 r., i to bardzo powoli, zaczęły następować zmiany w tym zakresie. Temu zresztą Piwowarski dawał wyraz w swoich szerszych zainteresowaniach: pluralizmem religijnym, wychowaniem w rodzinie, rytuałami, katolicką nauką społeczną, moralnością. Dzieło zmarłego w 2001 r. W. Piwowarskiego z wielkim rozmachem kontynuuje Mariański, którego zainteresowania, wyrażające się w licznych publikacjach książkowych i artykułach, są bardzo szerokie ${ }^{28}$. Obejmują one zarówno dyskusję przedstawionych tu teorii socjologicznych przemian, sekularyzację ${ }^{29}$, rolę religii w przestrzeni publicznej, znaczenie Kościoła rzymskokatolickiego w życiu społecznym, krytykę i dyskusję teorii w odniesieniu do doświadczeń obecnych w polskim społeczeństwie. Bardzo ważne jest też to, że Mariański zajmował się i zajmuje się nadal kwestiami, które są jako najbardziej aktualne dyskutowane w środowiskach naukowych socjologów religii na świecie, a do nich należy bez

${ }^{27}$ Co jednak bardzo istotne, postawę badawczą Piwowarskiego określała mocna orientacja empiryczna i przywiązanie do metod badawczych socjologii, co między innymi było przyczyną sporu pomiędzy nim a Majką, który, będąc z wykształcenia także filozofem i teologiem, nie oddzielał perspektywy socjologicznej od ujęć normatywnych tak pryncypialnie. Por. J. MARIAŃSKI, Socjologia religii w ujęciu ks. Wtadysława Piwowarskiego, w: Socjologia religii ks. Wtadystwa Piwowarskiego, red. A. Wójtowicz, Warszawa: PTS 2004, Sekcja Socjologii Religii, s. 20-44.

${ }^{28}$ Bardzo duża część dorobku Mariańskiego wiąże się z socjologią moralności, obejmując tak ważne publikacje, jak podręczniki z zakresu socjologii moralności, por. Socjologia moralności, red. J. Mariański, Lublin: Wydawnictwo KUL 2006, czy fundamentalne dzieło Leksykon socjologii moralności, Kraków: Zakład Wydawniczy Nomos 2015.

${ }^{29}$ Por. np. J. MARIAŃSKI, Między sekularyzacją i ewangelizacją. Wartości moralne $w$ świadomości młodzieży szkót średnich, Lublin: TN KUL 2003; Sekularyzacja i desekularyzacja w nowoczesnym świecie, Lublin: Wydawnictwo KUL 2006. 
wątpienia rozwijana przez niego socjologia duchowości. Jak konstatuje w jednej z książek poświęconych tej tematyce:

Obecnie socjologowie religii są o wiele bardziej ostrożni w wydawaniu jednoznacznych ocen dotyczących religijności współczesnych społeczeństw niż ich koledzy sprzed kilku dekad XX wieku. W warunkach sekularyzacji coraz bardziej widoczne są także procesy desekularyzacji $\mathrm{w}$ sensie rozwijania się autonomicznej religijności i duchowości. W Europie Bóg nie umarł - jak twierdzą krytycy religii, ale też nie jest tak żywy - jak twierdzą niektórzy teologowie i socjologowie. Europa Zachodnia balansuje między sekularyzacją i desekularyzacją ${ }^{30}$.

\section{ZAKOŃCZENIE}

W pierwszym okresie rozwoju socjologii religii dominowało ustanowienie przedmiotu badań, definiowanie religii i śledzenie jej dynamiki rozwoju oraz zarysowywanie pola badań empirycznych. Przedmiotem debaty w tym okresie było pytanie o siłę sprawczą religii i socjologowie pokazywali, że jest ona w wielu przypadkach decydująca dla kształtu życia społecznego. W okresie późniejszym oś sporów stanowiły rozmaite odpowiedzi na pytanie o to, czy religia upada czy nie i jakie są takiego lub innego rozstrzygnięcia dowody. Obecnie za dominujący problem należy uznać zatarcie się granicy pomiędzy religią i niereligią, czy inaczej - rozszerzenie rozumienia religii na takie jej formy, które parę dekad wcześniej nie byłyby widziane „w związku” z religią. Przy czym najważniejsze jest to, iż nie stanowi to tylko problemu terminologicznego dla socjologów religii. Chodzi o to, że rzeczywiście w warunkach ponowoczesności sacrum przybiera rozmaite formy, które trudniej niż religie tradycyjne poddają się konceptualizacjom i które także jest trudniej badać. Takie frazy, jak believing without belonging, patchwork religijny, religijność koktajlowa itp. oddają tę formę religii, która coraz częściej jest - jak w metaforze Luckmanna - niewidzialna.

$\mathrm{Z}$ perspektywy postaw dominujących w Polsce może to nie być zrozumiałe. Bo w Polsce religia dalej jest elementem oczywistości społecznej, szczególnie w wymiarze jak najbardziej widzialnym - praktyk religijnych i rytuałów. Europa pod tym względem od Polski bardzo się różni, ale pozostałe kontynenty - już nie. Otóż we Francji czy Anglii, w krajach skandynawskich, a w ostatniej dekadzie także we Włoszech, Hiszpanii i Irlandii, a z drugiej strony, w większości krajów postkomunistycznych, dominujący jest swoisty eklektyzm religijny i brak przywiązania do tradycyjnej religijnej aktywności. Dobrym przykładem tego

${ }^{30}$ J. MARIAŃSKI, Sekularyzacja - desekularyzacja - nowa duchowość. Studium socjologiczne, Kraków: Zakład Wydawniczy Nomos 2013, s. 18. 
typu zjawisk jest to wszystko, co w swoim czasie socjologowie umieszczali pod wspólnym mianownikiem New Age. Z jednej strony można twierdzić, że New Age to, czasem nawet wyrafinowana, nauka, z drugiej, że to różne formy terapii i treningi, z trzeciej - że magia, a z czwartej - no właśnie - że religia, która w sobie te wszystkie elementy mieści. Jednak jeśli religia, to zupełnie inaczej zorganizowana niż religie tradycyjne, co właśnie dobrze wyraża dylemat granicy demarkacyjnej między tym, co religią jeszcze jest, a co nią już nie jest.

Wyrazy masowego żalu po śmierci księżnej Diany w Wielkiej Brytanii, składane kwiaty, zapalane znicze, były interpretowane jako forma „zastępczej” religii. Ale na takie rozumienie tych zachowań pozwala szerokie rozumienie religii, bez związku z instytucjami religijnymi, gesty mają charakter związku z sytuacją ostateczną, jaką jest śmierć (tu księżnej Diany, bardzo lubianej), niekoniecznie jednak wiążą się z jakąkolwiek formą transcendencji. Z drugiej strony, takie kontynenty jak Afryka, Ameryka Lacińska pozostają religijne, i dotyczy to rozmaitych tradycji religijnych, także tradycji chrześcijańskiej, w obrębie której intensywnie rozwijają się Kościoły zielonoświątkowe.

Z tych przykładów wynika wprost to, co stanowi trafną charakterystykę współczesnej sytuacji religijnej świata - zróżnicowanej, takiej, w której z jednej strony w Europie ma miejsce eklektyzm religijny, deinstytucjonalizacja, nowe społeczne formy religijne, $\mathrm{z}$ drugiej zaś publiczne religie czerpią swoje znaczenie z innych zasobów - nie tylko z subiektywnej religijności, ale także z potencjału tradycji i znaczenia instytucji religijnych w życiu społecznym.

Wydaje się, że przyszłość rozwoju socjologii religii wpisze się w kontynuację i innowację jednocześnie. Jako symboliczny obraz kontynuacji można widzieć duże badania międzynarodowe i porównawcze analizy, z drugiej - małe jakościowe studia, innowacyjne metodologicznie, które mają na celu pogłębienie rozumienia obecnej, ponowoczesnej społecznej formy religii. Badania takie prowadzone są także w Polsce. Socjologia religii po ponad stu latach rozwoju w pewnym sensie wraca do punktu wyjścia - religijna różnorodność świata, konieczność zwrócenia uwagi na inne niż chrześcijaństwo tradycje, żywotność islamu, odmienność organizacyjna niechrześcijańskich religii, współistnienie „chłodnego" religijnie zachodu Europy z „gorącą" religijnie resztą świata wszystko to stawia przed socjologią religii nowe wyzwania. I zawsze aktualny przy tym jest postulat, by nie tracić związków z głównymi teoretycznymi nurtami socjologii ogólnej. 


\title{
BIBLIOGRAFIA
}

BERGER P.: Święty baldachim. Elementy socjologicznej teorii religii, thum. W. Kurdziel, Kraków: Zakład Wydawniczy Nomos 1997.

BoROwik J.: Sociology of Religion in Central and Eastern Europe after 1989, w: Eastern European Religion, red. E. Revay, M. Tomka, Budapest-Piliscaba: Pazmany Tarsadalomtudomany 2006.

Casanova J.: Religie publiczne w nowoczesnym świecie, tłum. T. Kunz, Kraków: Zakład Wydawniczy Nomos 2005.

Hervieu-Leger D.: Religia jako pamięć, thum. M. Bielawska, Kraków: Zakład Wydawniczy Nomos 1999.

MAJKA J.: Religijność wiejska w warunkach urbanizacji: studium socjologiczne, Warszawa: Biblioteka „Więzi” 1971.

MAJKA J.: Religijność miejska w regionie uprzemysłowionym: studium socjologiczne, Warszawa: Biblioteka „Więzi” 1977.

MARIAŃSKI J.: Sekularyzacja i desekularyzacja w nowoczesnym świecie. Studium socjologiczne, Lublin: Wydawnictwo KUL 2006.

MARIAŃSKI J.: Sekularyzacja - desekularyzacja - nowa duchowość. Studium socjologiczne, Kraków: Zakład Wydawniczy Nomos 2013.

NorRis P., Inglehart R.: Sacrum i profanum. Religia i polityka na świecie, tłum. R. Babińska, Kraków: Zakład Wydawniczy Nomos 2006.

PIWOWARSKI W.: Socjologia religii, Lublin: Redakcja Wydawnictw KUL 1996.

ZIELIŃSKA K.: Spory wokół teorii sekularyzacji, Kraków: Zakład Wydawniczy Nomos 2009.

ZwIERŻDŻYŃSKI M.K.: Gdzie jest religia? Pięć dychotomii Thomasa Luckmanna, Kraków: Zakład Wydawniczy Nomos 2006.

\author{
OD SEKULARYZACJI \\ DO POWROTU RELIGII NA SCENĘ PUBLICZNĄ: \\ TRENDY ROZWOJOWE ŚWIATOWEJ SOCJOLOGII RELIGII \\ Z UWZGLĘDNIENIEM DOROBKU \\ LUBELSKIEJ SZKOŁY SOCJOLOGII RELIGII W POLSCE
}

Streszczenie

Artykuł przedstawia kluczowe etapy rozwoju socjologii religii, a na tym tle prezentowane jest znaczenie badań naukowych w tym zakresie, prowadzonych na Katolickim Uniwersytecie Lubelskim. Pierwszą fazę rozwoju prezentują klasycy socjologii religii, Emilé Durkheim i Max Weber, których zręby rozumienia religii są wkomponowane w całościowe wizje społeczeństwa. Oni też w swoich teoriach zawarli przesłanki dla rozumienia sekularyzacji, które były rozwijane przez następne pokolenia socjologów religii. Autorka stawia tezę, że teorie sekularyzacji i dyskusje wokół niej były ważnym elementem powstania nowych teorii, w tym ważnej koncepcji religii publicznej José Casanovy. 
Na tle światowych trendów w rozwoju socjologii religii zaprezentowane są osiągnięcia socjologów pracujących na Katolickim Uniwersytecie Lubelskim, których dorobek badawczy i publikacyjny zyskał miano lubelskiej szkoły socjologii religii. Wśród nich szczególnie zasłużyli się ks. Franciszek Mirek, ks. Józef Majka, ks. Władysław Piwowarski i ks. Janusz Mariański, których najważniejsze zasługi są w artykule omówione, na tle rozwoju dyscypliny w Polsce.

Słowa kluczowe: socjologia religii; socjologia religii w Polsce; lubelska szkoła socjologii religii; klasycy socjologii religii; sekularyzacja; religia publiczna

\author{
FROM SECULARIZATION \\ TO THE RETURN OF RELIGION TO PUBLIC LIFE: \\ WORLD TRENDS IN DEVELOPMENTS OF SOCIOLOGY OF RELIGION \\ WITH ATTENTION TO THE ROLE OF LUBLIN SCHOOL \\ OF SOCIOLOGY OF RELIGION IN POLAND
}

S u m m a r y

The article present crucial points in development of sociology of religion, and the role of research conducted at Catholic University of Lublin is presented at this background. The first faze is presented by achievements of classics in the field, Emilé Durkheim i Max Weber, who their understanding of religion implemented to the holistic concepts of society. They also in their theories observed some elements of secularization process, that later were developed by the next generations of sociologists of religion. Author thesis is that theories of secularization were formative for development of the reflection on the changing social role of religion and had an impact on further theories of religion, including the influential concept of José Casanova about the return of religion to public life.

The role of sociologist from the Catholic University of Lublin, known as school of sociology of religion from Lublin, is presented on this background. Achievements of the main figures, such as fr. Franciszek Mirek, fr. Józef Majka, fr Władysław Piwowarski and fr. Janusz Mariański, with taking into account influence of their research on sociology of religion in Poland.

Key words: sociology of religion; sociology of religion in Poland; Lublin school of sociology of religion; classics of sociology of religion; secularization; public religion 